\title{
Sustainable energy supply and consumption by 2050 and outlook towards the end of the century: Possible scientific breakthroughs
}

\author{
Lennart Bengtsson, Elisabeth Rachlew, \\ Friedrich Wagner
}

\section{INTRODUCTION}

A project launched by the European Academies' Science Advisory Council (EASAC) in 2013 identified possible areas of scientific breakthroughs in energy supply and consumption with a long-term perspective up to and beyond 2050 .

The project facilitated interactions and information sharing among scientists in Europe and worldwide through electronic communications and two dedicated workshops. A steering committee with eighteen scientists from eleven countries was appointed by the EASAC participating academies (Box 1). The first workshop concentrated on nuclear energy and explored its possible future scientific and technological developments, while the second workshop addressed renewable energies, energy systems and storage (Table 1). The papers presented in this Special Issue were written by experts who participated in the project and benefitted from the opportunities for international information sharing and discussion.

The main sources of energy supply addressed during the project were carbon-based fossil fuels, solar photovoltaics, biofuels and nuclear. Whilst energy efficiency was an essential issue throughout the discussions and special consideration was given to the energy efficiency of engines and appliances, particular attention was given to the future of electricity grids, electricity storage and fuel cells. Lastly, concerning energy consumption, there was an important focus on energy for transport.

One important conclusion from this project is that the energy issue should not be split up into independent contributions: electricity, heat, mechanical work, etc. The transformation to a largely $\mathrm{CO}_{2}$-free energy supply requires that the chemical energy forms are replaced predominantly by electricity. Even more than in the past, an energy policy and development strategy requires keeping in mind the total picture-energy generation, energy transportation and energy usage and each area calls for increased research. Even if a timespan for this transition of more than thirty years does seem long, we nevertheless have to conclude that fossil energy will still be in the energy mix for a long time globally. Therefore, we have to accept the unavoidable need to develop carbon capture and storage techniques, even if Europe could escape to employ this technology. MacElroy (2016) points out clearly the present situation and what research is needed for the future for closing the carbon cycle. Furthermore, the technological development in nuclear energy could alleviate the question of long-term storage of high level nuclear waste. Nuclear fusion research has the chance within the next decade to demonstrate the feasibility of this concept and to demonstrate that a fusion reactor could be an option in the longterm energy mix which is highlighted in the article by Horvath and Rachlew (2016).

Wind and solar power have shown a remarkable growth in many countries inside and outside Europe. In countries like Germany, the added installed power level matches peak demand. The efficiency of the solar cells has reached levels where solar cell panels could give considerable contributions to the energy mix in most European countries. Still, new materials might emerge with even better photovoltaic properties. Several basic science research areas within the fields of solar and biofuels are highlighted. The article by Inganäs and Sundström (2016) highlights the 


\begin{tabular}{|l|}
\hline Box 1 EASAC steering committee for the Breakthrough study \\
\hline Lennart Bengtsson, KVA; cochair, lennart.bengtsson@mpimet.mpg.de \\
Elisabeth Rachlew, KVA; cochair, erk@kth.se \\
Dick Hedberg, KVA; dickh@kva.se \\
Sven Kullander, KVA; (deceased January 2014) \\
Olle Inganäs, Linköping, Sweden; ois@ifm.liu.se \\
Villy Sundström, Lund, Sweden; villy.sundstrom@chemphys.lu.se \\
Eva-Mari Aro, Turku, Finland; evaaro@utu.fi \\
Ilkka Savolainen, Helsinki, Finland; ilkka.savolainen@vtt.fi (left June 2013) \\
Matthias Beller, Leibniz, Germany; Matthias.beller@ catalysis.de \\
Thomas Hamacher, München, Germany; thomas.hamacher@tum.de \\
Johan Carlsson, JRC, The Netherlands; johan.carlsson@ec.europa.eu \\
Samuele Furfari, Brussels, Belgium; sfurfari@ulb.ac.be \\
Krzysztof Zmijewski, Warsaw, Poland; Krzysztof.zmijewski@interia.pl \\
Vicente Carabias, Switzerland; cahu@zhaw.ch \\
John Holmes, EASAC, United Kingdom; jholmes2@btinternet.com \\
Don MacElroy, Dublin, Ireland; don.macelroy@ucd.i.e. \\
Akos Horvath, Budapest, Hungary; horvath.akos@energia.mta.hu \\
Constantino Vayenas, Patras, Greece; cgvayenas@upatras.gr
\end{tabular}

possible development for photovoltaics to enter in a large scale with more efficient, resilient and economic solar panels and takes a look into the research development of the materials needed. The scene of the many functionalities of biofuels is painted by Aro (2016) in her article, which highlights where worldwide research is flourishing.

The introduction of intermittent electricity sources into the production requires more planning and changes to the distribution net which is modelled and discussed in the paper by Kuhn et al. (2016). In many countries most of the fossile contributions come from the transport sector which would need a transformation to electric vehicles and/or a combination with fuel cells. Both these issues are discussed in the articles by Furfari (2016) and by Niakolas et al. (2016).

Some basic science and major technology research areas have not been included, such as development of chemical and electrical storage systems, and development of new materials (for nuclear reactors, for batteries, for solar panels, for cables), in order to focus this issue more towards the generation of the energy needed for the future.

In summary, the seven papers included give an overview of fields in energy research which could promise essential progress in low-carbon energy supply and use.

Acknowledgments The EASAC breakthroughs project has been financially supported by the Royal Swedish Academy of Sciences through Knut and Alice Wallenberg foundation, the Nobel Institutes for Physics and Chemistry, the Swedish Natural Science Research Council, the Swedish Energy Authority, the Greifswald branch of IPP, MPG and the European Commission's Joint Research Centre (JRC).

Open Access This article is distributed under the terms of the Creative Commons Attribution 4.0 International License (http:// creativecommons.org/licenses/by/4.0/), which permits unrestricted use, distribution, and reproduction in any medium, provided you give appropriate credit to the original author(s) and the source, provide a link to the Creative Commons license, and indicate if changes were made. 
Table 1 The project has included the following meetings besides the four meetings of the steering committee: Workshop on the future of nuclear energy, Greifswald, April 8-9, 2013 (http://www.easac.eu/energy/wg-low-carbon-energy.html) and Workshop on renewables, storage and systems, KVA, Stockholm, September 20-21, 2013 (http://www.kva.se/en/Science-in-Society/Energy-Committee/Breakthroughs-in-SustainableEnergy/)

\begin{tabular}{|c|c|c|}
\hline Researcher & Institution & Title of presentation \\
\hline \multicolumn{3}{|c|}{ Workshop on the future of nuclear energy } \\
\hline Hamid Aït Abderrahim & MOL, Belgium & Future Advanced Nuclear Systems And Role of MYRRHA \\
\hline Hardo Bruhns & Düsseldorf, Germany & $\begin{array}{l}\text { Framework aspects for the use of nuclear power in the } \\
\text { longer-term future }\end{array}$ \\
\hline Ákos Horváth & Budapest, Hungary & $\begin{array}{l}\text { New projects in Eastern Europe and the sustainability of } \\
\text { nuclear energy }\end{array}$ \\
\hline Boris Kuteev & Moscow, Russia & $\begin{array}{l}\text { Possible outcome of fusion-fission power plant by } 2050 \text { and } \\
\text { beyond }\end{array}$ \\
\hline Alex C. Mueller & CNRS, Paris, France & $\begin{array}{l}\text { Pyroprocessing and fast reactors by } 2050 \text {-reflections on } \\
\text { pros and cons }\end{array}$ \\
\hline Friedrich Wagner & IPP, Greifswald, Germany & More effective energy distribution on a European scale \\
\hline Robert Wolf & IPP, Greifswald, Germany & Fusion research and Wendelstein $7-\mathrm{X}$ \\
\hline Friedrich Wagner & IPP, Greifswald, Germany & Options of nuclear fusion beyond 2050 \\
\hline \multicolumn{3}{|c|}{ Workshop on renewables, storage and systems } \\
\hline Paul Alivisatos & Lawrence Berkeley National Laboratory, USA & Nanoscience and the future of the Global Carbon Cycle \\
\hline Karl Leo & Technical University Dresden, Germany & $\begin{array}{l}\text { Recent progress in organic solar cells: From a lab curiosity } \\
\text { to a serious photovoltaic technology }\end{array}$ \\
\hline Markus Antonietti & $\begin{array}{l}\text { Max Planck Institute of Colloids and Interfaces, } \\
\text { Germany }\end{array}$ & $\begin{array}{l}\text { Lactid acid, ionic liquids and energy storage materials- } \\
\text { Perspectives of Hydrothermal Biomass Upgrade }\end{array}$ \\
\hline Eli Yablonovitch & University of California Berkeley, USA & Photovoltaics, high efficiency together with low cost \\
\hline René J. Janssen & Technical University Eindhoven, The Netherlands & Efficient polymer solar cells and first steps beyond that \\
\hline Frank Dimroth & Fraunhofer-Gesellschaft, Germany & $\begin{array}{l}\text { Photovoltaic research for the support of European energy } \\
\text { transition }\end{array}$ \\
\hline Magnus Borgström & Lund University, Sweden & Nanowires with promise for high efficiency photovoltaics \\
\hline Anders Hagfeldt & Uppsala University, Sweden & Hybrid inorganic-organic photovoltaics- $-\mathrm{HI}-\mathrm{OPV}$ \\
\hline Klaas Hellingwerf & University of Amsterdam, The Netherlands & $\begin{array}{l}\text { Cyanobacteria as the ultimate photo-catalysts of the } \\
\text { conversion of carbon dioxide into chemical commodities } \\
\text { and liquid fuel, driven by either sunlight or electricity }\end{array}$ \\
\hline Per Gardeström & Umeå Plant Science Center, Sweden & Energy and green chemicals from forest products \\
\hline Sascha Rexroth & Ruhr University Bochum, Germany & Rational design of cyanobacteria for hydrogen production \\
\hline Vincent Artero & CEA, France & $\begin{array}{l}\text { Molecular science for artificial photosynthesis: from bio- } \\
\text { inspired catalysts to nanomaterials }\end{array}$ \\
\hline Erwin Reisner & University of Cambridge, UK & $\begin{array}{l}\text { Artificial photosynthesis with enzymes and synthetic } \\
\text { catalysts integrated in nanostructured hybrid materials }\end{array}$ \\
\hline Daniel Nocera & Harvard University, USA & The artificial leaf (was hindered to participate) \\
\hline Styrbjörn Styring & Uppsala University, Sweden & Artificial photosynthesis \\
\hline Michel Armand & The National Center for Scientific Research, France & Electrochemical energy storage, activity on all fronts \\
\hline Thomas Hamacher & Technical University Munich, Germany & $\begin{array}{l}\text { Integration of renewable energies: competition between } \\
\text { storage, the power grid and flexible demand }\end{array}$ \\
\hline Hermann-Josef Wagner & Ruhr University Bochum, Germany & Wind energy systems- present status and ecobalances \\
\hline Godfrey Boyle & The Open University, UK & $\begin{array}{l}\text { Renewables-intensive Energy Systems for the United } \\
\text { Kingdom }\end{array}$ \\
\hline Ujjval Vyas & Alberti Group, USA & $\begin{array}{l}\text { The importance of failure and the future of renewable } \\
\text { energy }\end{array}$ \\
\hline Sture Larsson & $\begin{array}{l}\text { Former Technical Director and deputy Director } \\
\text { General at Svenska Kraftnät, the Swedish Power } \\
\text { System Operator (TSO), Sweden }\end{array}$ & Requirements for system adaptions to intermittent energies \\
\hline
\end{tabular}




\section{REFERENCES}

Aro, E.-M. 2016. From first-generation biofuels to advanced solar biofuels. Ambio (Suppl. 1). doi:10.1007/s13280-015-0730-0.

Furfari, S. 2016. Energy efficiency of engines and appliances for transport on land, water, and in air. Ambio (Suppl. 1). doi:10. 1007/s13280-015-0734-9.

Horvath, A., and E. Rachlew. 2016. Nuclear power in the 21st century: Challenges and possibilities. Ambio (Suppl. 1). doi:10. 1007/s13280-015-0732-y.

Inganäs, O., and V. Sundström. 2016. Solar energy for electricity and fuels. Ambio (Suppl. 1). doi:10.1007/s13280-015-0729-6.

Kuhn, P., M. Huber, J. Dorfner, and T. Hamacher. 2016. Challenges and opportunities of power systems from smart homes to supergrids. Ambio (Suppl. 1). doi:10.1007/s13280-015-0733-x.

MacElroy, J.M.D. 2016. Closing the carbon cycle through rational use of carbon-based fuels. Ambio (Suppl. 1). doi:10.1007/s13280015-0728-7.

Niakolas, D.K., M. Daletou, S.G. Neophytides, and C.G. Vayenas. 2016. Fuel cells are a commercially viable alternative for the production of "clean" energy. Ambio (Suppl. 1). doi:10.1007/ s13280-015-0731-z.

\section{AUTHOR BIOGRAPHIES}

Lennart Bengtsson participated actively in the development of the European Centre for Medium-Range Weather Forecasting (ECMWF), where he was the Head of Research (1975-1981) and Director (1982-1990). He then served as the Director of the Max Planck Institute for Meteorology in Hamburg, Germany, from 1991 to 2000. Since 2000, he has been a Professor at the University of Reading,
United Kingdom. He was the Director of the International Space Science Institute in Bern, Switzerland, from 2008 to 2013.

Address: Max Planck Institute for Meteorology, Hamburg, Germany and Environmental Systems Science Centre, Reading, UK.

e-mail: lennart.bengtsson@mpimet.mpg.de

Elisabeth Rachlew $(\square)$ is a Professor of Applied Atomic and Molecular Physics at Royal Institute of Technology, (KTH), Stockholm, Sweden. Her research interests are in basic atomic and molecular processes studied with synchrotron radiation, and development of diagnostic techniques for analysing the performance of fusion experiments, in particular, the development of photon spectroscopic diagnostics. She is a member of the physics class of the Royal Swedish Academy of Sciences.

Address: Department of Physics, Royal Institute of Technology, 10691 Stockholm, Sweden.

e-mail: erk@kth.se

Friedrich Wagner joined Max Planck Institute for Plasma Physics in 1975, and was made the Head of the ASDEX tokamak experiment in 1986 and appointed Scientific Fellow in 1988. He was a member of the Directorate of IPP from 1993 to 2005, Speaker of the Greifswald Branch Institute from March 1999 till April 2007 and the Head of the "Wendelstein 7-X Enterprise" from 2003 till 2005. Since 1999, he is Ordinary Professor at the Ernst-Moritz Arndt University in Greifswald. Besides his commitments at the institute, he was the Chairman of the Plasma Physics Division of the European Physical Society from 1996 till 2004, and he was the President of the European Physical Society from 2007 till 2009.

Address: IPP, Max Planck Gesellschaft, Greifswald, Germany.

e-mail: friedrich.wagner@t-online.de 